\title{
I. Dünya Harbinde Osmanlı Devleti ve Abhazya
}

Mesut Erşan*

\section{Özet}

Kafkasya, tarihin her döneminde büyük devletlerin ilgi alanı içinde olmuş, ve büyük devletlerin istilalarına maruz kalmıştır. Genel olarak son üç yüz yıllık dönemde iki büyük ve önemli gücün mücadelesine sahne olan bu coğrafyada, Rusya ve Osmanlı Devleti arasında yaşanan çatışmalar, hem bölge tarihi hem de dünya tarihi açısından önemli sonuçlar doğurmuştur. Özellikle Kafkaslardan Osmanlı Devletine yönlendirilen zorunlu göç ve Bolşevik Rusların Kafkaslarda yol açtığı yeni düzen, Türk-Rus ilişkilerinde yeni ve zorlu bir dönemi başlatmıştır. Bu iki önemli gücün Karadeniz'in doğu sahillerindeki mücadelesinde, stratejik Abhaz toprakları ve Abhaz halkı önemli rol oynamıştır.

Bu makalede özellikle I.Dünya savaşının son yıllarında Abhazya bölgesinde cereyan eden olaylar, Osmanlı, Rus, Gürcü ve Abhaz ilişkileri çerçevesinde ele alınarak değerlendirilmeye çalışılmıştır.

Anahtar Kelimeler: Osmanlı Devleti, Abhazya, I.Dünya Savaşı, Kafkasya

\section{Ottoman Empire and Abkhazia in World War I}

\section{Abstract}

Caucasia has been in the interest area for great states at every period of history and geography of Caucasia has exposed to invasion of these great states. Conflicts was lived between Ottoman State and Russia caused important results not only for region history but also for world history in the geography where witnessed two big and important power struggle at the last three century generally. Especially compulsory migration directed to Ottoman State from Caucasia and new order done by Bolshevik Russia at Caucasia started new and hard period for relationship of Turks and Russians. Abkhzaian land and Abkhazian community played an important role at the struggle between these two major power at the eastern coasts.

\footnotetext{
* Prof. Dr., Eskişehir Osmangazi Üniversitesi, Fen-Edebiyat Fakültesi, Tarih Bölümü, mersan@ogu.edu.tr. (ORCID ID: 0000-0003-4057-9945).
}

(Makale Gönderim Tarihi: 23.07.2017, Makale Kabul Tarihi: 27.10.2017). 
Events happened in the area of Abkhazia, especially at the last years of World War I in the frame of relationships between Ottoman, Russia, Georgian and Abkhazia is tried to evaluated in this study.

Keywords: Ottoman Empire, Abkhazia, World War I, Caucasia

\section{Giriş}

Osmanlı Devleti'nin Kafkasya ile ilk ilişkileri XV.yüzyılın ikinci yarısında başlamış; 1451 - 1454'te Abhazya bölgesi ele geçirilmiş, 1475'deki Kırım seferiyle Kuzey Kafkasya'daki Terek ve Kuban nehirleri arasındaki bölgeler, 1479 'da da Anapa, Taman ve Koba iskeleleri fethedilmiştir. Karadeniz hakimiyeti yolunda ilerleyen Osmanlıların Kafkasya'dan ilk fethettikleri yerler bu Abhaz toprakları olmuştur ${ }^{1}$. Dolayısıyla 16.yy. başlarında Osmanlı Devleti vasıtasıyla İslamiyetle tanışan Abhazya'da yaklaşık 300 yıl sürecek bir Osmanlı Hakimiyeti başlamıştır². XVI. yüzyıldan itibaren Rusya'nın bölgeyle ilgilenmesi üzerine Kafkasya üzerindeki mücadeleler Rusya, Osmanlı Devleti ve İran arasında XVII ve XVIII. yüzyıllarda da devam etmiştir. 1768-1774 Osmanlı Rus savaşını kaybeden Osmanlı Devleti'nin Kafkasya'daki

\footnotetext{
${ }^{1}$ M. Fahrettin Kırzıoğlu, Osmanlıların Kafkas Ellerini Fethi, (1451-1590), Ankara 1976, s.7 .(Makalede yararlanılan kaynaklara sadık kalınarak hem "Abhaz" hem de "Abaza" terimleri kullanılmıştır. Hangisinin doğru kullanıldığı konusunda Murat Papşu'nun "Bir Adlandırma Sorunu: Abhaz mı Abaza mı?" başlıklı makalesinden alıntıladığım şu bilgiler herhalde tatmin edici olur. "...Gürcülerin Abhazya'daki komşuları Abazalara verdikleri "Aphazi" adı Ruslar tarafından "Abhaz" olarak benimsendi. Kuzey Kafkasya'daki Tapanta (Bashağ) ve Asharuva grupları ise "Abaza" adını korudular, fakat o da Rusçada milliyet adlarının sonuna eklenen bir takıyla "Abazin" olarak yerlesti. Çarlık döneminde ortaya çıkan ve Sovyetler Birliği'nin "milliyetler politikası"yla iyice yerleşen bu ayrım sonucunda "Abhazlar" ve "Abazinler" akraba fakat ayrı iki halk olarak kabul edildi.Yani Abhaz ve Abazin Abazaların iki grubuna Rusçada verilen adlardır. Abhazya'daki Abazalar "Abhaz", Rusya'ya bağı Karaçay-Çerkes Cumhuriyeti'nde yasayan Abazalar "Abazin" olarak adlandırılır. Rusça aracılığıyla geçtiği Batı dillerinde de genellikle böyle kullanılır. Türkçede ise yüzyıllardır var olan "Abaza" adı böyle bir ayrım içermez. Ancak 1950'li yıllardan itibaren yayınlanmaya başlayan Kafkas dergileri aracılığıyla, o zaman bu konuya kafa yormayan yazar ve çevirmenler "Abhaz" ve "Abazin" adlarını Rusçadan Türkçeye ithal ettiler. 90'lı yıllardan itibaren Kafkasya'dan bilgi akısının artmasıyla birlikte "Abhaz" ve "Abazin" kullanımı daha da yaygınlaştı". Murat Papşu, "Bir Adlandırma Sorunu, Abhaz mı Abaza mı?" Nart, iki Aylık Düşün ve Kültür Dergisi, S.51, Eylül-Ekim 2006.

2 Justin Mc Carty, Ölüm ve Sürgün, Çev. Bilge Umar, İstanbul 1998, s.41.
}

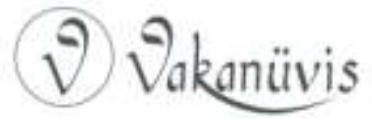


durumu, Küçük Kaynarca Antlaşması ile Kırım'a bağımsızlık verilmesi ve 1783'te de Kırım'ın Rusya tarafından ilhakı üzerine sarsılmıştır. 1783 tarihinde Kırım'ın Ruslarca ilhakıyla Osmanlı Devleti Kafkasya'ya daha fazla önem vermeye başlamış, Ferruh(Ferah) Ali Paşa'nın Soğucak Muhafızlığına atanmasıyla bölgenin kaderi değişmiştir ${ }^{3}$. İslamiyetin bölgede yayılmasıyla Osmanlı Devleti lehinde sağlanan politik üstünlük 1828-1829 Osmanlı-Rus savaşından sonra imzalanan Edirne Antlaşması ile kaybedilmiştir ${ }^{4}$. Ruslarla yapılan bu savaşı bölgedeki Lazların, Avarların, Batı Gürcistan halklarının, Abazalar ile Çerkeslerin desteklerine rağmen kaybeden Osmanlı Devleti, Edirne Anlaşması'nın 4.maddesi ile Kafkasya'daki bütün haklarından vazgeçmiştir. Osmanlı Devleti, Çerkesya üzerindeki haklarını bu arada Kuban Irmağı ile Bzıb Irmağı arasındaki Karadeniz kıyı kontrolünü Rusya'ya devretmiştir. Çerkesya'daki Anapa ve Sucuk-kale(Soğucak-Kale, şimdiki Novorossiysk) limanları/kaleleri dışında, Poti Limanı, Ahıska ve Ahilkelek Rusya'ya bırakılmıştır ${ }^{5}$.

Kafkasya'da bu gelişmeler yaşanırken Abhazya'daki Osmanlı egemenliği Rus saldırıları sonucunda, daha erken bir tarihte, 1810 yılında sona ermiştir ${ }^{6}$ ve bu tarihten itibaren Abhaz-Rus çatışmaları

3 Cemal Gökçe, Kafkasya ve Osmanlı Imparatorluğunun Kafkasya Siyaseti, İstanbul 1979, s. 38.

4 Muahedât Mecmuası, C.IV/2., İstanbul 1298 ,s.72-73; İsmail Berkok, Tarihte Kafkasya, ìstanbul 1958, s.416.

${ }^{5} 1829$ Edirne Antlaşmasının, Kafkasya ile ilgili olan maddeleri: 1- Rusya Tuna nehrinin dışında, geri çekilecek.2- Kafkasya'da Poti, Anapa, Ahıska, Ağırkelek Ruslar'ındır, bu yerlerin dışında Ruslar geri çekilecek, Osmanlı Kafkasya'da Rus hâkimiyetini tanıyacak. (Böylece Osmanlı Kafkasya'da hâkimiyet iddiâsından vazgeçiyordu.) 3- Rus ticâret gemileri boğazlardan serbestçe geçebilecek. Rus tüccârlar serbestçe ticâret yapabilecek. 4- Osmanlı; Rusya, İngiltere, Fransa ile yaptığı -sonucunda Yunanistan'ın bağımsız olduğu- protokolü kabûl edecek.5-Osmanlı, Rusya'ya 10 milyon duka altın tazmînât ödeyecek. (Stanford J. Shaw- Ezel Kural Shaw, Osmanlı Imparatorluğu ve Modern Türkiye, İstanbul 2000, C.2., s .60-61.; Nihat Erim, Devletlerarası Hukuk ve Siyasi Tarih Metinleri, C.I, Ankara 1953, s.280-281.)

6 1787-92 ve 1806-12 tarihleri arasında meydana gelen Osmanlı-Rus savaşları neticesinde de bölgede önemli bir değişiklik olmamıştır. Rusya'nın Kafkasya'da yayılma çabaları, Kafkas kavimlerinin bitmek tükenmek bilmez bir hırsla Ruslara karşı koymaya çalışmaları Osmanlı Devleti'nin giderek azalan maddi desteğine rağmen Kafkas halklarının kendilerini Osmanlı tabiliği altında görmeleri bu yılların genel manzarasını teşkil eder. 1783'ten sonraki yıllarda İmam Mansur önderliğinde Rus işgaline direnen Kafkasyalılar 1830'lardan sonra, Osmanlı Devleti'nin bölgeyle daha az ilgilenmesi ve

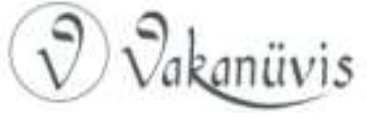


başlamıştır ${ }^{7}$. Rusya'nın Kafkasya sınırlarına doğru ilerlemesi burada yeni bir sorun meydana getirmiş ve bu, Abhaz yönetici çevresinde "Rus yanlısı" ve "Türk yanlısı" grupların ortaya çıkmasına yol açmıştır. Sonuçta Abhazya'nın hükümran prensi Georgi Çaçba'nın (Şervaşidze) başvurusu üzerine Çar I. Aleksandr, 17 Şubat 1810 tarihli manifestosuyla Abhazya'nın Rusya'ya ilhakını, Abhaz halkının ise "Rusya Imparatorluğu'nun yüksek himayesi, Çarlık küresi ve koruması altında bulunduğunu" ilan etmiştir.

1852 yılının ilkbaharında Naip Muhammed $\mathrm{Emin}^{8}$, Çerkes kabilelerini genel bir toplantıya davet ederek Kafkas Müslümanlarının Rus esaretinden kurtarılması için Osmanlı Devleti'nin Rusya ile harb edeceğini içeren bir konuşma yapmış, halkın güvenini ve desteğini sağlayarak Ruslara karşı mücadeleye başlamıştı. Kırım harbinin başlaması üzerine Bâbıali, Muhammed Emin'e "Paşa" rütbesi vererek Çerkezistan'daki mücadelesinde onu desteklerken diğer yandan da İstanbul'da bulunan Çerkes beylerinden Sefer Bey'i "Paşa" rütbesiyle Çerkezistan'a göndererek Ruslara karşı faaliyete geçmesini sağladı ${ }^{9}$. Ancak Sefer Bey'le Muhammed Emin bölgede birbirleriyle mücadeleye

meydanı Ruslara bırakmasına rağmen İmam Gazi Muhammed, Hamzat Bek, Şeyh Şamil ve Hacı Murad önderliğinde, Kafkas tarihinin en şanlı direniş hareketlerini gerçekleştirmişlerdir. İmam Şamil, Dağıstan'da devam ettirdiği mücadelenin iyi neticelere ulaşması için Batı Kafkasya'nın yani Çerkezistan'ın da Ruslara karşı cephe almasının lüzumlu olduğuna kani olarak bu ülkeye idare ve teşkilatta öncü $\mathrm{Hacl}$ Muhammed ve Süleyman gibi naibleri göndermiş ve bunlar Ruslara karşı önemli başarılar kazanmışlardır. (Şerafettin Erel, Dağıstan ve Dağıstanlılar, İstanbul 1961, s.151.

${ }^{7}$ Özdemir Özbay, Dünden Bugüne Kuzey Kafkasya, Ankara 1995, s.67.

8 "Muhammed Emin, Şamil tarafından naib olarak 1848 yılında Kuban Çerkeslerine gönderildi.1850'ye kadar Abadzehleri daha sonra Natuhayları ve Şapsığları yönetti. Kırım Savaşı sırasında (1854'te)müttefik komutanlığının daveti üzerine Çerkes elçilerin başında Varna'ya gitti... Eylül 1855'te Türk başkomutanı Ömer Paşa tarafından "Tüm Batı Kafkasya Kuvvetlerinin Komutanı" ilan edilerek "paşa" rütbesi verildi. Şamil'in teslim olmasından sonra durumu güçleşti...Yerel düzenin, toprağın ve sınıfsal statülerin korunması, vergiden ve askerlikten muafiyet şartıyla mücadeleyi bıraktığını açıkladı..Türkiye'ye göç ederek Bursa'nın Armutlu köyüne yerleşti. 1863'te burada öldü". (Rodina No 3-4, 1994, Naibı Şamilya, Murat Korkmasov'dan naklen, A.Fonwill, Çerkesya Bağımsızlık Savaşı(1863-1864) (Fransız Askeri Danışmanının Anılarından), İstanbul 1996, s.42.)

${ }^{9}$ N. Luxemburg, Rusların Kafkasyayı İşgalinde Ingiliz Politikası ve Imam Şamil, İstanbul 1998, s.251.

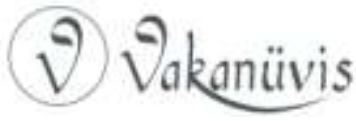


giriştiler ve ayrı cephelerde Ruslara karşı mücadeleye devam ettiler. Kırım Harbinde Ruslara karşı mücadeleye devam eden Muhammed Emin Paşa 1856'da İstanbul'a dönmüştür. İstanbul'dan yeniden Kafkasya'ya dönüşünde de Sefer Bey ile aralarında ki husumet devam etmiştir. Aynı yıl Serasker Rıza Paşa'nın yaveri Ömer Bey Kafkasya'ya gelerek Abhazya bölgesinde Naip Muhammed Emin Paşa ile görüşmüş ve kendisinin destekleneceği sözü verilmiştir. 1859 yılında ise Şamil'in Dağıstan'da Ruslara esir düşmesi üzerine Muhammed Emin Paşa da mücadelesine son vererek İstanbul'a dönmüştür ${ }^{10}$

Osmanlı Devleti'nin müdahalelerine rağmen bölgede hakimiyet tesis eden Rusya, ilk zamanlarda Abhazya'nın iç yönetimine ve geleneksel yapısına karışmadı. Ancak 1864'te hükümran prenslik lağvedildi ${ }^{11}$. Çerkeslerin ana göçünden $(1864)^{12}$ üç yıl sonra merkezinde Sohumkale'nin bulunduğu yörede yerleşik Abazaların kendi yurtlarından sürülmesine sıra geldi. 1867'de başlayan zorunlu göçe karşı Abazaların etkili bir direniş gösterecek durumları yoktu. Bölgede bulunan İngiliz Konsolosu Gifford Palgrave'in belirttiğine göre Abhazya ve çevresindeki yörelerin Müslüman halkının dörtte üçünün göçe çıkacağı açıktı ve ona göre Ruslar yalnızca değerli arazilerdeki Müslüman halkı oralardan söküp atmak amacını değil, bir yandan da "ülkesinin kıyı bölümlerine, açlıktan kıvranan ve tek meteliği olmayan bir dindaşlar yığını böylece fırlatılıp atılacak olan Türk devletini zor duruma sokmak amacını gütmekte idiler"13. Ancak Abhazlar Karadeniz limanlarına ulaştığında Osmanlı Hükümeti daha hazırlıklı idi.

\footnotetext{
${ }^{10}$ Erel, a.g.e., s. 158.

${ }^{11}$ Konstantin Zatulin-Yuri Ançabadze, Gürcistan-Abhazya Anlaşmazlığı Dünü, Bugünü, Çözüm Perspektifleri, 1998, s. 1. (Bütün Abhazların mevcudu 1830-1840 tarihlerindeki tahminlere göre 128.000 kadardır. (Gökçe, a.g.e., s.8).

${ }^{12}$ Çar 1861 'de Ekaterinodar'da Çerkes liderleriyle görüştü. Çerkeslerin büyük bir kısmı Ruslarla uzlaşmaya yanaşmadılar. Bunun üzerine Rus askeri hareketleri 1862 'de yeniden başladı. 1864'te de bir Rus birliğinin Tuapse'ye girmesiyle hareket sona erdi. Ruslar Çerkezistan'ın verimli topraklarının servetine sahip olmak istiyorlardı. Bu sebeple yüz- binlerce insanın Osmanlı İmparatorluğu topraklarına göçmesine engel olmadılar. Bu kitle göçünde en az dört yüz bin Çerkez Kafkasya'yı terk etti. Bu insanlara on binlerce Çeçen, İnguş, Abzeh ve Acaralı da katıldı. Altıyüzbinden fazla insan karayoluyla Anadolu'ya göçtü.(Paul B.Henze, Kafkaslarda Ateş ve Kıllı̧: Kuzey Kafkasya Dağ Köylülerinin Direnişi, (çev:Akın Kösetorunu), Ankara 1985, s. 28).

${ }^{13}$ Mc Carty, a.g.e., s. 36-37.
}

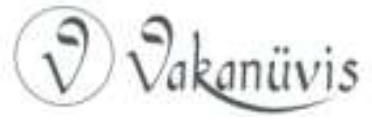


Osmanlılar Abazalara daha özenli ilgi gösterdiler ve onların arasında hastalıktan ileri gelen telefat daha az sayıda oldu.

\section{Harbinde(1877-1878) Abhazya'da Osmanlı-Rus Mücadelesi}

II. Abdülhamid 1877-1878 Osmanlı-Rus harbinde Rusları başka yönlerden de meşgul etmek, kuvvetlerini bölerek zayıflatmak amacıyla Kafkasya'daki Müslümanları göreve çağırmıştır ${ }^{14}$. Bu cümleden olarak Rusya'nın savaş ilanından hemen sonra Kafkasya Müslümanları üzerinde büyük nüfuzu olan Şeyh Şamil'in büyük oğlu Mehmet Şamil'e paşalık rütbesi verilerek Erzurum'a yollanmış, onun ve bazı Dağıstanlı beylerin yardımları ile Dağıstan kabileleri Ruslara karşı ayaklandırılmaya çalışılmıştır. Diğer yandan Abaza beyleri de Ruslara karşı Abaza ve Çerkes kabilelerini ayaklandırmayı taahhüt ettiklerinden Batum'dan Sohum'a gönderilmişlerdir ${ }^{15}$. Savaş boyunca Ruslar için büyük tehlike oluşturan Osmanlı stratejisi, deniz yolundan Abhazya'ya bir şaşırtma saldırısı yapılması üzerine planlanmıştı. 12 Mayıs 1877'de Osmanlı Devleti Sohumkale'nin kuzeyine asker çıkardı. Küçük Rus garnizon birlikleri kaçtı. Çıkarılan bu birlikler arasında on yıl önce Osmanlı İmparatorluğuna kaçmış olan ve şimdi hala Kafkasya'da bulunan kendi halklarının kalıntılarını Rusya'ya karşı ayaklandırmak isteyen Çerkeslerle Abhazlar da vardı. Kıyı bölgelerinin Abhazları da Ruslarla çarpışmak üzere Osmanlı ordusuna katıldılar ${ }^{16}$. Bu beylerin yardımları ile toplanan üç bin kadar Abaza Sohumkale'yi ele geçirmişler, bu başarının İstanbul'da duyulması büyük sevinç yaratmış onları desteklemek için Ferik Fazıl Paşa komutasında muntazam fırka Sohum'a gönderilmiştir. Bu başarı üzerine Padişaha "Gazi" unvanı verilmiştir" ${ }^{17}$. Ancak bölgedeki bu olumlu gelişmeler savaşın Osmanlı Devleti'nin aleyhinde sonuçlanması üzerine sona ermiş ve Kafkasya Müslümanlarına yapılan baskıların artması üzerine Kafkasya'dan dalga dalga muhaceret başlamış, Osmanlı Devleti de bölgede önemli

\footnotetext{
${ }^{14}$ Cezmi Eraslan, "II.Abdülhamit ve Kafkasya Müslümanları", Kafkas Arastırmaları I, İstanbul, Tarihsiz, s. 54.

${ }^{15}$ Mahmut Celalettin Paşa, Mirat-ı Hakikat, (neşr.:ismet Miroğlu), İstanbul 1983, s. 374.

${ }^{16}$ Mc.Carty, a.g.e., s. 116.

${ }^{17}$ Mahmut Celalettin Paşa, a.g.e., s. 385.
}

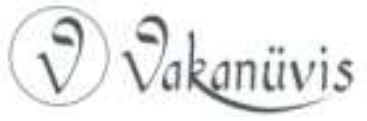


gördüğü yerlerde şehbenderlikler açarak bölgeyle olan bağlarını sürdürmeye çalışmıştır.

Öte yandan 1877-1878 Savaşı'nda Abhazların Osmanlı Devleti'ni desteklemiş olmaları Ruslar tarafından cezalandırılmalarına sebep oldu. Ruslar, Abhazya bölgesindeki 60.000 desiatiden ${ }^{18}$ fazla toprağa Rusya'nın iç bölgelerinden getirilen göçmenleri yerleştirdi. Planlı bir şekilde yapılan yerleştirme sonucu Abhaz yerleşim birimleri Rus göçmen gruplarıyla kuşatılarak yöre halkı dağlara çıkmaya veya Türkiye'ye göçe zorlandı. Dolayısıyla 300 yıl süren Kafkas-Rus savaşlarının Rusların galibiyeti ile sonuçlanmasıyla bütün Kuzey Kafkasya'da olduğu gibi Abhazya'da da halk çok büyük felaketler yaşadı ve Abhaz tarihinin en büyük nüfus kaybına ve kıyımına neden oldu. Abhazlar, nüfuslarının 5/6'sını ya ölümlerle ya da Anadolu'ya göçlerle yitirdi $^{19}$. Boşalan Abhazya topraklarına Gürcüler, Ruslar, Ermeniler, Rumlar, Estonlar ve diğer haklar yerleştirildi ${ }^{20}$.

\section{I.Dünya Savaşında Osmanlı-Abhaz İlişkileri}

I.Dünya Savaşının en önemli cephelerinden biri hiç şüphesiz Kafkas Cephesi idi. Osmanlı Devleti bu cephede Ruslara karşı müttefiki Almanya $^{21}$ ile birlikte hareket etti. Osmanlı Devleti'nin genel siyaseti Kafkasya'nın bağımsızığını kazanması ve Rusya ile Türkiye arasında bağımsız tampon bir devletin kurulması idi ${ }^{22}$. Bu suretle Türkiye, Rus tehlikesinden kurtulabilirdi. Bu bağlamda Enver Paşa'nın Kafkas siyaseti de 1913'te şekillenmeye başlamıştı. Onun planına göre

\footnotetext{
${ }^{18}$ Bir desiati 1.050 hektar.

${ }^{19}$ XIX.yüzyılın başında Abhazların nüfusu yaklaşık 300 bin iken 1897'de tüm Rusya çapında yapılan nüfus sayımında sayıların sadece 56 bin olduğu belirlenmiştir.(Guram Gumba, "XIX.Yüzyıl Rus-Kafkas Savaşı ve Sürgün Problemi", Geçmişten Günümüze Kafkasların Trajedisi, İstanbul 2006, s. 169).

${ }^{20}$ Cahit Aslan, "Türk-Rus-Gürcü İlişkilerinin Merkezindeki Ülke: Abhazya", Akademik Bakış, S. 16, Ankara 2009, s. 3.

${ }^{21}$ Almanya'nın Kafkasya siyasetinin ana esasları ve amacı I.Dünya Savaşının ağır ekonomik yükünü imparatorluğunun üzerinden kaldırmak, ordusunun ve ülkesinin temel ihtiyaç maddelerini karşılamak için Kafkasların zengin kaynaklarına nüfuz etmek, Azerbaycan'ın petrolleri, Gürcistan'ın magnezyum yatakları, çelik, kereste ve buğdayından istifade etmekti. (Serpil Sürmeli, Türk-Gürcü ilişkileri (1918-1921), Ankara 2001, s. 59.

${ }^{22}$ Akdes Nimet Kurat, Türkiye ve Rusya, Ankara 1990, s.508.
}

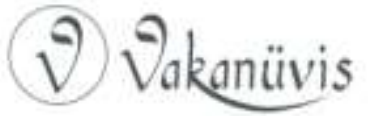


Kafkasya en önemli cephelerden birini oluşturmaktaydı. O, Kafkasya'daki Türk ve Müslümanları Rus despotizminden kurtaracak, onların bağımsızlığını kazanmalarını sağlayarak, "Büyük Turan" devletini kuracaktı. Bu yolla Osmanlı'nın yalnızlığına son verilecek, güçlü ve stratejik konuma sahip bir dost devlete kavuşulacaktır ${ }^{23}$. Enver Paşa'nın bu stratejisini gerçekleştirmek için beklediği fırsat savaşın sonlarına doğru ortaya çıkmış Kafkas milletleri kendi kaderlerini tayin etmek için harekete geçmişlerdi. I.Dünya Savaşı içinde Şimali Kafkas dağılarının 3 Mayıs 1917'de Terkkala'da topladıkları kongreye Dağıstan Çeçen-Inguşya Osetya, Karaçay Balkarya ve Abhaz temsilcileri ${ }^{24}$ katılmıştı ${ }^{25}$. Bu toplantıda birlik içindeki Şimali Kafkasyalı unsurların muhtariyete sahip olacakları siyasi bir birlik teşkil edecekleri kararı alınmıştı ${ }^{26}$. 18-20 Eylül 1917 tarihleri arasında Andi'de Kafkasya Dağlı Halklarının 2. Kurultayı düzenlendi. Kurultay sonunda Kuzey Kafkasya Halk Cumhuriyeti'nin kurulmasına karar verildi ${ }^{27}$.

Kafkasya geneli için bu gelişmeler yaşanırken Abhaz halkının 8 Kasım 1917 tarihindeki kurultayında seçilen Birinci Abhaz Halk Konseyi temsilcileri(A.Şervaşidze, T.Marşan, S.Basarya) Mayıs 1918'de Türk hükümetine başvurmuş ve Batum Konferansı'nda “Abhazya'nın Transkafkasya halkları grubuna dahil olmak istemediğini; Osmanlı Devleti himayesi altında yapılandırılmasını istedikleri Kafkasya Dağlıları Birliği içinde yer aldığını beyan etmişlerdi ${ }^{28}$. Ancak yüzbin kişilik nüfusuyla Şimalî Kafkas Cumhuriyeti içinde önemli bir yere sahip

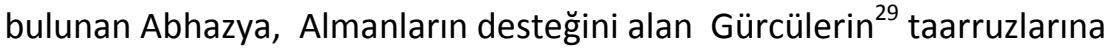
maruz kaldi ${ }^{30}$.

${ }^{23}$ Kazım Karabekir, Cihan Savaşına Neden Girdik? Nasıl idare Ettik?, Cilt: 1, (İstanbul, 1938), s.285.

241917 yılı sonu ve 1918 yılının başlarında Kafkasya Dağlıları Birliği Hükümeti'nde Abhazya'yı önce Simon Basarya sonra da Simon Aşkhatsaa temsil etti (Selçuk Sımsım, 19. ve 20. Yüzyıl Abazaların Politik Tarihi (1770-1993), İstanbul 2016, s.253).

${ }^{25}$ Mustafa Beştoy, "11Mayıs 1918 Kuzey Kafkasya'da milli Cumhuriyetin Kuruluşu, Kuzey Kafkasya'da Çarlık Emperyalizmi ve Cumhuriyet Devri”, 11 Mayıs 1918 Şimalî Kafkasya'nın Istiklali, İstanbul 1965, s.23.

${ }^{26}$ Beştoy, a.g.e., s. 23.

${ }^{27}$ Sımsım, a.g.e., s. 248.

${ }^{28}$ Sımsım, a.g.e., s. 260.

${ }^{29}$ Türkiyenin müttefiki olmasına rağmen Almanya tek başına Kafkasya'yı Türkiyeye kaptırma niyetinde değildi. Bu nedenle Batum konferansına bir temsilci göndermiş

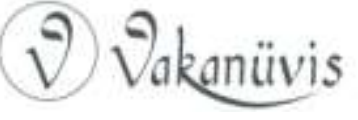


Batum'da yapılan görüşmelerde Abhaz murahhaslar Şimalî Kafkas ile birlikte olduklarını ve katiyen bu birlikten ayrılmak tasavvurunda bulunmadıklarını tekrar etmişlerdi ${ }^{31}$. Gürcü murahhaslar ise Abhaz kıtasının Gürcistan'a iltihak edileceği ümidinde olduklarını beyan ediyorlardı $^{32}$. Kafkas işleri ile doğrudan ilgilenen Enver Paşa, Abhazya meselesi ile de yakından ilgileniyordu. Nitekim daha 18 Mayıs 1918' de Süleyman Sabri Bey'i Sohumkala'ya göndermiş ve o da Marşan Dadaş Bey ile diğer Abhaz ileri gelenlerini Batum'a getirmişti ${ }^{33}$. Ayrıca kendisine yardımcı olmak üzere Rüşdi ve Aziz Beylerin derhal Batum'a gönderilmelerini istemişti ${ }^{34}$.

Öte yandan bölgede bulunan Osmanlı güçlerince burada yaşanan gelişmeler yakından takip ediliyor, özellikle de Almanların Gürcülerle olan ilişkileri ve bölgedeki faaliyetleri dikkatle izleniyordu. Bu bağlamda Abhazya bölgesindeki Alman-Gürcü faaliyetleri konusunda Şark Orduları Grubundan, Başkumandanlığa gönderilen Kafkasya'ya dair muhaberatta özetle şunlar belirtiliyordu ${ }^{35}$ : "3 Haziran 34-Poti'den

ancak bu girişim Türkiyeyi Kafkasya'da durdurmaya yetmemişti. Alman temsilci General Otto von Lossov'un Batum ve Poti'de Gürcülerle imzaladığı birtakım anlaşmalarla Almanya Kafkasyaya Gürcüler vasıtasıyla müdahil oluyordu.(Enis Şahin, Diplomasi ve Sınır, Gümrü Görüşmeleri ve Protokolleri, 1918, İstanbul 2005, s. 85.

30 “17 Mayıs 1918'de Gürcistan'ın da içinde bulunduğu Güney Kafkasya Seyminin askeri birlikleri bölgenin merkezi olan Sohum'u ele geçirmiş, Gürcistan'ın 26 Mayıs 1918'de Güney Kafkasya seyminden ayrılmasından sonra da Abhazya, Gürcü birliklerinin elinde kalmıştır" . (Araz Arslanlı, "Bölgesel ve Küresel Dengeler Açısından Abhazya Sorunu", Karadeniz Araştırmaları, Sayı 5, (Bahar 2005) s.120.)

${ }^{31}$ Ati, 26 Haziran 1334/1918 Numro 177

${ }^{32}$ Ati, 26 Haziran 1334/1918 Numro 177; 9 Şubat 1918'de Tiflis'te Abhaz Halk Konseyi ile Gürcistan Halk Meclisi arasında bir toplantı yapılmış, bu toplantıda Gürcistan ile Abhazya arasındaki ilişkilerin kurulmasına ilişkin anlaşma akdedilmişti.(Sımsım, s.254).

${ }^{33}$ ATASE, Dos.61 Kls.1847 Fihr.6/16 ; Ayrıca Şimalî Kaf kas delegesi Haydar Bammatof Şimalî Kafkasya'daki Abhazya hükumetinin temsilcisi Simon Basarya'nın olağanüstü bir delegesinin kendisiyle beraber İstanbul'a gönderilmesi teklifinde bulunduğunu bildiriyordu. (ATASE, Dos.369 Kls. 526 Fihr.6.

${ }^{34}$ ATASE, Dos.61 Kls.1847 Fihr.6/17 Türkiye ile Azerbaycan, Gürcistan, Ermenistan ve Şimalî Kafkasya delegelerinin katılımıyla gerçekleştirilen Batum'daki görüşmeler döneminde, Türk hükümetinin Kafkasya Stratejisi şu esasa dayanıyordu:Rusya'nın yokluğunu azami ölçüde değerlendirmek, Kafkasya 'da daha önce ki mücadeleler sırasında kaybedilen Türk arazilerini geri almak, Türk sınırını Türkiye'nin çıkarları doğrultusunda çözmek.( Şahin, a.g.e., s. 154).

${ }^{35}$ ATASE, Dos.184 Kls.3194 Fihr.3

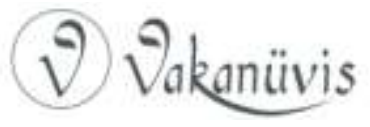


Sohum'a gönderilen kırkaltı Alman neferi ve Alman zabiti Sohum'a çıkarak orada Alman bayrağı çektiler. İslamların silahlarını toplamaya başladılar. Hıristiyanları Gürcülerle beraber aleyhimize harbe girmeye icbar ediyorlar. Sohum Şimalî Kafkasya için hayat meselesidir. Şimalî Kafkas murahhasları bu gaileleri bertaraf etmek üzere asker ve cephane istiyorlar. "General" vapurunun iki tabur Alman askerini Köstence'den Poti'ye getireceğini haber aldım. Alman ve Gürcü kıtaatından mürekkeb bir kıtanın Viladikafkas istikametine tahriki haber alınmıştır"

19 Haziran 1334(1918) tarihli bir başka istihbarat raporunda ise "Şimalî Kafkasya'ya nakliye hakkında Gürcü Hükümeti cevap vermemiş olduğundan Şimalî Kafkas murahhasası Gürcistan'a şimalden erzak gönderilmeyeceği tarzında verdiği notaya Gürcistan Hükumeti "bu babda müzakere edebiliriz" tarzında cevap vermiştir.Ve heyet-i murahhasanın müracaatı üzerine Alman konsolosu, vürud edecek Alman ve Türk kıtaatı evvela Bakü'yü alacaklar ve sonra Şimalî Kafkas işlerine bakacaklardır tarzında konuşmakta" ${ }^{\prime 36}$ deniliyordu.

$\mathrm{Bu}$ istihbarat raporlarından da anlaşılacağı üzere müttefik Almanların desteği ile Gürcü idarecileri cesaretlendirilmiş, Osmanlı Devleti'nin bütün çaba ve itirazlarına rağmen Gürcüler Abhazya'da işgal ve yerleşme faaliyetlerine hız vermişlerdi. Nitekim Almanların da desteğini alan Gürcü kuvvetleri Abhazya ve Gürcistan arasında imzalanan 11 Haziran 1918 tarihli anlaşmanın 6. Maddesinden ${ }^{37}$ yararlanarak General Mazniev(Mazniaşvili) komutasında Abhazya'ya çıkarma yaptı. Abhazya Genel valisi olarak atanan Mazniev, 19 Haziran $1918^{\prime}$ den itibaren Abhazya'yı yönetmeye başladı ${ }^{38}$. Ağır şartlar altında varlığını sürdürmeye çalışan Abhazya'ya Kuzey Kafkas Cumhuriyeti, şiddetli çatışmalar nedeniyle destek veremedi ${ }^{39}$. Abhazya'nın bu suretle fiilen Gürcü yönetimi altına girmesi üzerine Aleksandr Şerveşidze(Çaçba),Tataş Marşan, Simon Basarya ve diğer nüfuzlu

\footnotetext{
${ }^{36}$ ATASE, Dos.184 Kls.3194 Fihr.3

3711 Haziran tarihli Abhaz-Gürcü Antlaşmasının 6. Maddesi:" Devrim düzeninin hızla yerleştirimesi ve kesin iktidarın organize edilmesi amacıyla Abhaz Halk Meclisi'ne destek olarak hükümetin emrine Kızıl Kuvvet Birliğ gönderilecektir.(Sımsım, a.g.e., s. 266).

${ }^{38}$ Simsım, a.g.e., s.267.

${ }^{39}$ Sımsım, a.g.e., s. 260.
}

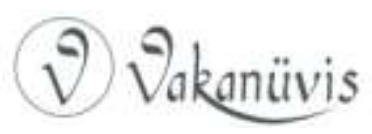


Abhazlar Türkiye'den yardım istediler ${ }^{40}$. Abhazya'daki karışık durum ve Abhazya'nın isteği üzerine bir miktar Osmanlı askerî Sohum'a gönderildi. Başlarında Binbaşı İsmail Hakkı, havacı üsteğmen Cemal Marşan, ve Süleyman Bganba'nın olduğu Osmanlı Ordusundaki Kuzey Kafkasyalı gönüllülerden oluşan ve "Sohum Müfrezesi" adı verilen birliklerle Abhazya'ya çıkartma yapıldı ${ }^{41}$. Ancak bu hem Gürcistan'ın hem de Almanya, Avusturya-Macaristan ve Bulgaristan'nın protestolarına sebep oldu ${ }^{42}$. Şark Orduları grubu komutanlığı ise verdiği cevapta "Sohum ve civarı ahalisiyle Abazaların Bolşeviklerin taarruzuna maruz kalması üzerine bir heyet-i murahhasanın kendilerine müracaatı üzerine ve onları muhafaza ve müdafaa maksadıyla bir müfrezenin gönderildiği; bunda bir istila maksadı olmadığı, maksadın himaye ve muavenetten ibaret olduğu bildiriliyor, ayrıca esasen Sohum, Gürcistan dahilinde olmayıp Şimalî Kafkas Hükümetine bağlı bulunduğundan bu olayın dostane ilişkileri etkilemeyeceği" ilave ediliyordu. Ağustos sonlarına kadar mücadele eden "Sohum Müfrezesi"nin Gürcü birliklerince yenilgiye uğratılması ile Türkiye'den yapılan bu yardım denemesi başarısızlıkla sonuçlandı ${ }^{43}$.

Diğer yandan İstanbul'daki Şimalî Kafkas Cemiyet-i Hayriyesi ${ }^{44}$ Abhazya olayları ile ilgili olarak Sohumkale'den gönderilen şikayetnameleri o günkü gazetelerde yayınlattı. 25 ve 30 Haziran 1918 tarihli Ati Gazetesi'nde yayınlanan şikayetnameler Abhazya'daki

\footnotetext{
${ }^{40}$ Sımsım, a.g.e., s. 268.

${ }^{41}$ Sımsım, a.g.e., s.268.

42"Gürcü Hükümetinin protestonamesi: Türkler, Sohum mıntıka müttefikimiz Abaza mıntıkasına asker intac ettiler.Bu hareketi Abaza ve Gürcü hükümetleri protesto eder.Bu hareketin tevkifi için tedabir ittihazını rica eder.( ATASE Dos.184 Kls.3194 Fihr.3) "Düvel-i Müttefika murahhaslarının protestoname hülasası: Sohum'a kıtaat-ı Osmaniye çıkarılmıştır. Sohum Gürcü kıtaatınca işgal edilmekte olduğundan bu hareket hukuk-ı beynelmilele mugayirdir. Vaziü'l-imza bizler işbu ittifak-ı mer'i devletlerinin sulh ve muhadenetle yaşadıkları Gürcülere karşı bu tarz-ı hareketi protesto eder ve kıtaat-ı Osmaniyenin hemen geri çekilmediği takdirde işbu hareketin Rusya ile. yeniden kat-ı münasebete sebep olacağı melhuz olduğunu nazar-ı dikkatlerine vazederiz."General Von Kres, Baron Frankeştayn,General Fetantayef) (ATASE, Dos.184 Kls.3194 Fihr.3).

${ }^{43}$ Sımsım, a.g.e., s.70.

${ }^{44}$ Cemiyet önce "Şimalî Kafkasya Cemiyet-i Siyasiyesi" adıyla kurumuş, mütarekeden sonra bu cemiyetin adı "Şimalî Kafkasya Muhacirleri Cemiyet-i Hayriyesi"ne dönüştürülmüştü.(Mustafa Butbay, Kafkasya Hatıraları, Ankara 1990, s.2)
}

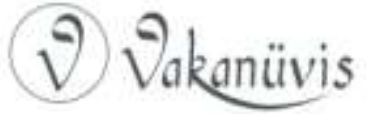


durumu gayet açıklıkla ortaya koyuyordu. Bu şikayetnamelere göre:"Gürcistan yalnız kendi istiklaliyle uğraşıyor. Fazla olarak halis bir Çerkes kabilesi olan Abazaları da kendisine ilhak için her türlü hile ve desiseye müracaat ediyor. Nitekim Gürcistan, Gürcistan'da kalmış olan otuz kırk kadar Alman neferiyle bir zabiti iğfal ve ikna ile sekizyüz kişilik bir Gürcü kuvvetini bunlara terfikan Abazalığa göndererek orayı cidden Gürcistan'a ilhaka uğraşıyor. Abazalığı ilhak etmek isteyen Gürcistan acaba hangi ve nasıl bir hakk-ı tarihîye istinad ediyor? Öteden beri kendilerini Çerkes bilen bu memleket ahalisi mukadderatlarını Şimalî Kafkas'ın istikbaline bağlamış bulunuyorlar ${ }^{45 " \prime}$

14 Ağustos 1334/1918 tarihinde Kuzey Kafkas murahhaslarının Sadrazam Talat Paşa'ya Abhazya meselesi ile ilgili olarak ilettiği şu bilgiler de Abhazya'da durumun gerçekten ciddî olduğunu ve Gürcülerin Abhazya'daki işgal faaliyetlerinin devam ettiğini gösteriyordu: "Gürcüler bütün islam Abazaların, Türk muhibbi olduklarından kanun harici muameleye tabi olacaklarını ilan etmişler. Ileri gelenleri Gürcü Sahra Divan-ı Harbi tarafından tevkif edilmiş veya kurşuna dizilmişlerdir. Gürcü hizmet-i askerîyesini kabul etmeyen bütün islam gençleri tevkif olunmaktadır. Belli başlı isimleri tadat edilen yirmiye yakın İslam karyeleri katliam edilmiş ve yağma, tahrib ve kamilen imha edilmiştir. Türkiye'den muavenet göremedikleri için Almanya Hükümetinin murahhası Von Karesi'ye yaptıkları müracaatlarına, Gürcüler aleyhine daha ziyade teşvik için Abaza mıntıkalarına Alman müfrezeleri sevk suretiyle cevap almışlar ${ }^{46 "}$.

Bu arada Abhazya'dan Batum'a gelen Abhaz liderlerinden Simon Basarya $^{47}$ Gürcülerin Abhaz topraklarını tamamen işgal ettiklerini açıkladı $^{48} \mathrm{ki}$ bu işgalden sonra Abhazya'dan İstanbul'a feryatnameler gelmeye başladı. Bu feryatnamelere göre "Rus ihtilalinden sonra geleceklerine sahip olmak ümidiyle yaşayan Abazalar yeni bir millî

\footnotetext{
${ }^{45}$ Ati, 25 Haziran 1334 S. 176.

${ }^{46}$ ATASE, Dos.369-2054 Kls.526 Fihr.28.

47 "Simon Basarya Abhazya Millet meclisi ve Şimalî Kafkasya delegesi aynı zamanda delegelerin İstanbul vekilidir. Rusya'da öğrenim yapmış vatansever bir gençtir" ( Mustafa Butbay, s.6.)(8 Kasım 1917'de Sohum Abhaz Halk Meclisi'nde yeni gerçek siyasi güç ve fiili hükümet organı olan Abhaz Halk Konseyi kuruldu ve Birinci AHK'ne Simon Basarya başkanlık etti.(Sımsım, a.g.e., s. 249).

${ }^{48}$ ATASE, Dos.369 Kls.526 Fihr.14.
} 
tehlike karşısında kalmışlardı. Kendisiyle komşu olmaktan başka ne tarihî ne de ırkî bir münasebeti bulunmayan Gürcistan, Abhazya'yı zorla boyunduruğu altına almak sevdasına düşmüş ve müthiş tecavüzlere başlamıştır. Bir hükümet vücuda getirmelerini müteakip ingur nehrini geçen ve kendileriyle bir münasebeti bulunmayan Sohumkala'yı zapteden Gürcüler son zamanlarda bu kadarla iktifa etmek istemediler. Abhazya içlerine doğru tecavüzlere başlayarak Gagra ve Tuapse'yi işgal ettiler. Gürcüler bu işgali Alman askerlerinin ve Sohumkala'ya gelen ü̧̈ Süvari Alayının yardımıyla gerçekleştirdiler. Memurlara üç ay zarfında Gürcüce öğrenmedikleri takdirde memuriyetlerini terk etmeleri gerektiğini tebliğ ettiler. Karadeniz şimendiferini, Gagra istasyonunu, bilumum emlak-ı umumiye-i nezaret altına aldılar. Askerî Vali olarak atanan General Mazine Şoyli'nin emriyle, Gadauta ve Gagra'ya Gürcü memurlar tayin etmek, Abhaz meclis-i millî içtimalarına Gürcü Cumhuriyeti namına resmi memurlar göndermek suretiyle Abhazya umur-ı dahiliyesine müdahale

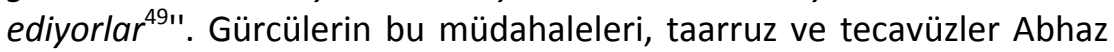
Millî Meclisinde protesto edilmesine rağmen devam etti. Gürcülerin bu hareketi karşısında bir çok yerde Abazalarla Gürcüler arasında çarpışmalar meydana gelmeye başladı. Alman ve Kazaklarla desteklenen Gürcüler karşısında yalnız kalan Abazalar, yine tek dayanakları olan Türkiye'den yardım istemeye karar verdiler. Abazalar yardım dileklerini şu şekilde dile getiriyorlardı: "Rusyaya karşı senelerce kahramâne bir surette müdafaa-i istiklal ve mevcudiyet eden Abhazlar şu dakikada bütün nazarlarını istanbul'a atfetmiş Türk kardeşlerinin kendileri hakkında gösterecekleri alakaya rapt-ı ümid eylemiş bulunuyorlar. Hükümet-i seniyyeden bizleri şu müşkil günlerimizde mazhar-ı himaye ve sahabet eylemesini rica ve istirham ederiz. Aksi takdirde Abhazya, Rus boyunduruğundan Gürcistan'ın dest$i$ esaretine intikal etmiş, Türkiye kendisine pek sadık bir mevcudiyet-i millîyeyi kaybetmiş olacaktır. Herhalde Türkiye maddeten bir şey yapmak istemese bile siyasî teşebbüsatiyle bizim imdadımıza koşabilir. Şimdilik bunu bekliyoruz ${ }^{50 "}$

\footnotetext{
${ }^{49}$ ATASE, Dos.730 Kls.527. Fihr.l/4.

${ }^{50}$ Ati, 28 Ağustos 1334/1918 Sayı 233.
} 
Öte yandan Gürcüler bu bölgedeki vatanseverleri Osmanlı hafiyesi addederek cezalandırdıkları gibi ${ }^{51}$, burada bulunan Türkleri de tevkif ediyorlardı ${ }^{52}$.Ayrıca yayınladıkları bildirilerde, varlığına son verdikleri Abhaz Millî Meclisi için "Türk memurlarının intihap ettirdiği mümessillerden mürekkeb Meclis-i Milli”" şeklinde bahsediyorlardı ${ }^{53}$.

Abhazya'daki bu olaylar üzerine Osmanlı Devleti'nin Şimalî Kafkasya nezdindeki askerî ve siyasî temsilcisi Yusuf İzzet Paşa'nın 11 Eylül 1334/1918 tarihinde bizzat Enver Paşa'ya çektiği telgrafta "Batum'da imzalanan antlaşma ile istiklali tasdik edilen Şimalî Kafkas Hükumet-i İslamiyesine ait bulunan Abhazya ve Tuapse'ye kadar olan Çerkezistan sahilinin Gürcü Hükümeti tarafından cebren ve harben ilhak edildiği, bunun Osmanlı Devleti'nin Karadeniz siyasetine büyük darbe vuracağı, Gürcülere Şimalî Kafkas Hükümeti tarafından en kısa zamanda bölgeden çekilmeleri ve tazminat ödemeleri talebinde bulunulduğu, bunun için şiddetli tedbirler alınması uygun görüldüğü takdirde kendisinin kumandanlık sıfatiyle hatt-ı harekete ait iradelerini beklediğini" bildirmiş, "ancak bu gibi şiddetli tedbirlerin iki hükümetin hayati menfaatlerine mugayir olacağı ve buna meydan verilmemesi gerektiği, fakat hiç olmazsa Şimalî Kafkas Hükümetinin Gürcistan'la olan sınırının tedkik ve tasdik olunmasının Hükumet-i Osmaniye için bir zaruret olduğu" uyarısında bulunmuştu ${ }^{54}$. Yusuf İzzet Paşa'ya 14 Eylülde cevap veren Enver Paşa "Şimal ve Cenubi Kafkas'ta emellerimiz dahilinde siyasî durumu halletmek üzere Sadrazam Talat Paşa'nın halen Berlin'de Alman siyasileriyle görüştügünü" bildiriyordu. Enver Paşa'nın beyanlarına göre; Gürcülerle Almanların Abhazya'da vücuda getirdikleri teşkilat ve olaylar hakkında Sadrazam Talat Paşa Berlin'de Gürcü hariciye Nazırı Çenkeli ile görüşmüştü. Çenkeli bu vukuata dair katiyen malumat almadığını ve kendi daire-i intihabiyesi olan Abhaz'da

\footnotetext{
${ }^{51}$ Ati, 4 Eylül 1334/1918 Sayı 240.

52 Ati, 13 Eylül 1334/1918 Sayı 249(Aynı gazetede yayınlanan ve Abhazya'dan gönderilen şu feryadname de oldukça anlamlıdır:.. "...Biz bedbaht Abazaların feryad-ı meyusanesine ihale-i sem' merhamet ediniz, müdahale ediniz, muavenet ediniz. Çünki mevcudiyetimiz saha-i alemden silinmek üzeredir.Sizin kan ve din kardeşiniz olduğumuz ve sizi sevdiğimiz için bizi mahvediyorlar. Abhazya'nın feryad-ı ihzarını işitmiyor musunuz?işitiyorsanız dest-i muavenetinizi uzatınız. itirazat-ı kırtasiye ile iktifa etmeyiniz. Çünkü eyyam-ı mevcudiyetimiz ma'duttur.)

${ }^{53}$ Ati, 4 Eylül 1334/ 1918 sayı 240.

${ }^{54}$ ATASE, Dos.369 Kls.526 Fihr.31/3.
}

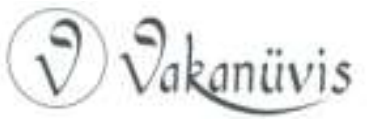


Müslümanlara hüsn-i muamele edilmesine tamamıyla taraftar olduğunu bildirmiş, buna karşı Talat Paşa tarafından bu halin devamının iki hükümet arasındaki dostluğa mani olacağı ve derhal hükümetinden telgrafla malumat talep etmesi ve münasip bir cevap alınmazsa vukua gelecek neticenin mes'ulünün Gürcü hükümeti olacağı Çenkeli'ye beyan edilmişti. Ayrıca Alman hükumeti nezdinde de bu konuda teşebbüsatta bulunulmaktaydı. ${ }^{55}$ Aynı tarihlerde (12 Eylül 1918) İstanbul'da bulunan Kuzey Kafkas Delegasyonu, AvusturyaMacaristan İmparatorluğu temsilcisi Guido Panfili'ye Abhazya'nın Gürcüler tarafından işgalini kınayan bir protesto notası verdi. 14 Eylül'de Viyana'ya ulaştıılan bu notada Abhaz halkının Kafkasya dağlıları Birliği içinde yer almaya karar verdiği belirtilerek Abhaz halkı için tek kurtuluşun yöreye ortak bir müttefik devletler(Alman,Avusturya-Macaristan, Türk, Bulgar) birliği gönderilmesi olduğu da yer almaktaydı ${ }^{56}$.

Diğer yandan Gürcü hükümeti Abhazya'yı işgal ederek kendi yönetimini sürdürmek çabalarına devam ediyordu. Abhaz Halk Konseyi'nin 1918 yılı Ekim ayı başında Abhazya'yı Gürcistan'ın silahlı mücadelesinden kurtarmak amacıyla devrim girişiminde bulunduğunu gerekçe gösteren Gürcü hükümeti tarafından 9-10 Ekim 1918'de Abhaz Halk Konseyi güç kullanarak dağıtılmış, birçok AHK üyesi tutuklanmış, Abhaz aydın sınıfının tüm önde gelen temsilcileri sürgün edilmiş ve Abhazya'da Gürcü işgali bütün ağırlığı ile hissedilmeye başlanmışti ${ }^{57}$.

Sonuç olarak Ekim devrimiyle birlikte özgürlük mücadelelerine sahne olan Kafkasya'da ve dolayısıyla Abhazya'da olaylar Osmanlı Devleti'nin genel durumuna bağlı olarak istenildiği gibi gelişmedi.30 Ekim 1918 tarihli Mondros Mütarekesi'nin çok ağır hükümlerinin Kafkasya ile ilgili olanları "iran'ın kuzey-batı kısmındaki Osmanlı kuvvetlerinin derhal harpten evvelki hudut gerisine alınması hakkında evvelce verilmiş bulunan emrin yapılması, Mâverâ-yı Kafkas'ın Osmanlı kuvvetleri tarafından kısmen boşaltılması emredilmiş olduğundan, diğer kısımları müttefikler tetkik ederek istediklerinde boşaltılması ve

\footnotetext{
${ }^{55}$ ATASE, Dos.369 Kls.526 Fihr.31

${ }^{56}$ Sımsım, a.g.e., s. 272.

${ }^{57}$ Sımsım, a.g.e., s. 273.
}

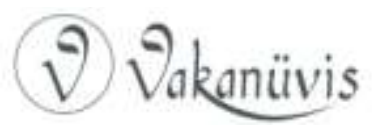


Mâverâ-yı Kafkas demiryolları da dahil tekmil demiryolları itilaf subay ve memurlarının idaresine bırakılacak, itilaf devletleri Batum ve Bakü'yü işgal edebilecektir" şeklinde idi ${ }^{58}$.

Kafkasya'da antlaşmalar harici olarak askerî harekât düzenlenen bölgelerin terki konusunda hassasiyet gösteren Sadrazam Ahmet İzzet Paşa 20 Ekim tarihinde Şimalî Kafkas ordu komutanlığına gönderdiği şifre telgrafta "müttefiklerle beraber bugün, mağlup bir vaziyette kalarak, şeref ve namus-ı millîmize mugayir olmayarak gösterilecek şartlar ile sulh temennisinde bulunduk"larını belirttikten sonra oldukça ilginç olan şu görüşleri ifade ediyordu: "Şimdi hükümetimizin hedef-i mesâisi olan bu vaziyet-i siyasiyeyi mümkün olduğu kadar elbirliği ile lehimize tebdil ve tağyire çalışmak ve sulh müzakeratına girinceye kadar düşmanlarımızın öteden beri bir cihan sulhu için ilan ettikleri esaslar haricine çıkmayarak bunlardan bizim elimizden gelecek kısımları şimdiden mevaki-i tatbike koymak ve bir taraftan mücavir hükümetlerle anasır-ı ecnebiyeyi tavr-ı hareketimizden hoşnut bırakmak suretiyle itimatlarını ve esna-yı sulhta lehimize hareketlerini mümkün olduğu kadar kazanmaktır. Binaenaleyh bu müessirat tahtında olarak hudud harici islamları muhafaza maksadıyla yapılan faaliyetlerden ve şimdiye kadar Kafkasya'da anasır-ı islamiyeye edilen muavenetlerin maatteessüf idamesine artık imkan kalmamıştır. Bu vaziyete göre Kafkasya'daki mevcudiyetimizin 26.10.1334 tarih ve 5267 numrolu emir mucibince seri bir surette kapanması ve Brest-Litovsk Muahedesi haricinde Iran ve Kafkasya'da işgal ettiğimiz arazinin hin-i tahliyesinde gösterilecek lüzumsuz hareketlerin memleketimizin mukadderat-ı atiyesine pek büyük zarar vereceğinden başka oldukları yerde kalmaları mültezim olan ahali-i islamiye için de vahim akibetler tevlid edeceği ehemmiyetle dikkate alınarak tahliyenin muntazaman ve hiç bir tarafın mutazarrır olmasına katiyen meydan vermeyerek icrasını te' kiden talep ederim" ${ }^{59}$. Ahmet İzzet Paşanın ifadesiyle artık Kafkasya'da Kafkas Müslümanları için yapılacak bir şey kalmamıştı. Zira girişilecek lüzumsuz bir harekat hem Osmanlı Devleti'ni hem de bölge

\footnotetext{
58 Türk İstiklal Harbi, Mondros Mütarekesi ve Tatbikatı, C.I, Ankara 1962, s.29-56; Birinci Dünya Harbinde Türk Harbi Kafkas cephesi, 3ncü Ordu Harekatı, C.II, Ankara 1993, s.628.

59 ATASE, Dos.369, Kls.526, Fihr.43; Dos.92, kls.3196, Fihr.11; 103 Sayılı Askeri Mecmuanın Tarih Kısmı, Sayı44, s.237.
}

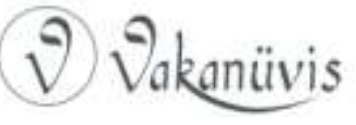


Müslümanlarını zor durumda bırakabilirdi. Bu kesin emirden sonra Kafkasya'da bulunan Türk kuvvetlerinin tahliyesi Kuzey Kafkas Ordusu

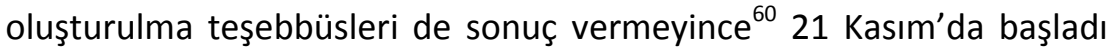
ve 29 Aralıkta 15.Piyade Fırkasının Batum'dan ayrılmasıyla son buldu. Bu suretle Osmanlı Devleti'nin I.Dünya Savaşı'nın en zor bir döneminde gerçekleştirdiği Kafkasya Harekatı sona erdi. Bu gelişme Abhazya için de kötü günlerin başlangıcı oldu. Osmanlı Devletinin bölgeyi terk etmesi kendi kaderiyle baş başa kalan Abhazya,içinde bulunduğu zor durumdan kurtulma çabalarına devam etti. Önce Ocak 1919'da General Denikin ile bir görüşme gerçekleştirdiler. Denikin İngiliz generalleri Forestie Wokker ve Miln'a yazdığı mektupta Abhazya bölgesinin tarafsız ilan edilmesini ve Abhazya'dan Gürcü yönetimini uzaklaştırılmasını talep etti. İngilizler Gürcistan'a 20 Mart 1919'da hiçbir bağlayıcılı olmayan "Abhazya'nın Özerkliği Tutanağı”nı kabul ettirmeye çalıştılarsa da bu çabalar da sonuç vermedi ve Abhazya'daki Gürcü Menşevik idaresi Abhazya'da Sovyet idaresi tesis edilinceye kadar devam etti ${ }^{61}$.

\section{Sonuç}

Tarihi boyunca bir çok devletin istilasına maruz kalan Kafkasya ve onun mütemmim cüzü Abhazya, Ekim devriminin getirdiği yeni konjonktür çerçevesinde yeni bir gelecek çabası içinde olmuş ancak bu çabalar yine hüsranla sonuçlanmıştır. Zira tarihin her döneminde bölgede hakimiyet sağlamak isteyen egemen güçlerin stratejileri Kafkasya'ya, dolayısıyla Abhazya'ya hep olumsuzluk olarak yansımış, I.Dünya Savaşında da aynı durum tekerrür etmiştir. Abhazya'nın tek halaskârı olarak yardımını talep ettiği Osmanlı Devleti'nin azamî çabaları yeterli olmamış, müttefiki Almanya'nın Gürcüleri himaye eden siyaseti Abhazya'nın geleceği üzerindeki çabaların önündeki en büyük engeli oluşturmuştur. Dolayısıyla Osmanlı Devleti için Karadeniz'in doğusundaki en stratejik üslerden birisini oluşturacak olan bu önemli coğrafya, kendi kaderiyle baş başa kalmıştır.

\footnotetext{
${ }^{60}$ Bu konuda bkz.:Mesut Erşan, "Yusuf İzzet Paşanın Kuzey Kafkas Ordusunu Oluşturma Teşebbüsü", Askeri Tarih Bülteni, Ağustos 2002, s. 53, ss:1-7.

${ }^{61}$ Sımsım, a.g.e., s.284.
} 


\section{Kaynakça}

Arslanlı, Araz, "Bölgesel ve Küresel Dengeler Açısından Abhazya Sorunu", Karadeniz Araştırmaları, Sayı 5, (Bahar 2005)

Aslan Cahit, "Türk-Rus-Gürcü illişkilerinin Merkezindeki Ülke: Abhazya", Akademik Bakış, S. 16, Ankara 2009.

ATASE Dos.184 Kls.3194 Fihr.3.

ATASE Dos.184 Kls.3194 Fihr.3.

ATASE Dos.369 Kls.526 Fihr.31/3.

ATASE Dos.184 Kls.3194 Fihr.3.

ATASE Dos.184 Kls.3194 Fihr.3.

ATASE Dos.369 Kls. 526 Fihr. 6

ATASE Dos.369 Kls.526 Fihr.14.

ATASE Dos.369 Kls.526 Fihr.31.

ATASE Dos.369-2054 Kls.526 Fihr.28.

ATASE Dos.61 Kls.1847 Fihr.6/16.

ATASE Dos.61 Kls.1847 Fihr.6/17.

ATASE Dos.730 Kls.527. Fihr.l/4.

ATASE Dos.369, Kls.526, Fihr.43.

ATASE Dos.92, kls.3196, Fihr.11.

103 Sayılı Askeri Mecmuanın Tarih Kısmı, Sayı 44.

Ati 13 Eylül 1334/1918 N. 249.

Ati 25 Haziran 1334 N. 176.

Ati 26 Haziran 1334/1918 N. 177.

Ati 26 Haziran 1334/1918 N. 177.

Ati 28 Ağustos 1334/1918 N. 233.

Ati 4 Eylül 1334/ 1918 sayı 240.

Ati 4 Eylül 1334/1918 Sayı 240.

Berkok, İsmail, Tarihte Kafkasya, ìstanbul 1958.

Beştoy, Mustafa, "11Mayıs 1918 Kuzey Kafkasya'da Millî Cumhuriyetin Kuruluşu, Kuzey Kafkasya'da Çarlık Emperyalizmi ve Cumhuriyet Devri", 11 Mayıs 1918 Şimalî Kafkasya'nın istiklali, ìstanbul 1965.

Birinci Dünya Harbinde Türk Harbi Kafkas Cephesi, 3ncü Ordu Harekatı, c. II, Ankara 1993.

Butbay, Mustafa, Kafkasya Hatıraları, Ankara 1990.

Eraslan Cezmi, "Il.Abdülhamit ve Kafkasya Müslümanları", Kafkas Araştırmaları I, İstanbul Tarihsiz.

Erel, Şerafettin, Dağıstan ve Dağıstanlılar, İstanbul 1961.

Erim, Nihat, Devletlerarası Hukuk ve Siyasi Tarih Metinleri, C. I, Ankara 1953. 
Erşan, Mesut, "Yusuf Izzet Paşanın Kuzey Kafkas Ordusunu Oluşturma Teşebbüsü", Askeri Tarih Bülteni, Ağustos 2002, s.53.

Fonwill, A., Çerkesya Bağımsızlık Savaşı-1863-1864 (Fransız Askeri Danışmanııın Anılarından), istanbul 1996.

Gökçe, Cemal, Kafkasya ve Osmanlı imparatorluğunun Kafkasya Siyaseti, istanbul 1979.

Gumba, Guram, "XIX.Yüzyıl Rus-Kafkas Savaşı ve Sürgün Problemi", Geçmişten Günümüze Kafkasların Trajedisi, ìstanbul 2006.

Henze, Paul B., Kafkaslarda Ateş ve Kılıç: Kuzey Kafkasya Dağ Köylülerinin Direnişi, (çev: Akın Kösetorunu), Ankara 1985.

Kazım Karabekir, Cihan Savaşına Neden Girdik? Nasıl Idare Ettik?, C. 1, İstanbul 1938.

Kırzıoğlu, M. Fahrettin, Osmanlıların Kafkas Ellerini Fethi (1451-1590), Ankara 1976.

Kurat, Akdes Nimet, Türkiye ve Rusya, Ankara 1990.

Luxemburg, N., Rusların Kafkasyayı Işgalinde Ingiliz Politikası ve Imam Şamil, İstanbul 1998.

Mahmut Celalettin Paşa, Mirat-ı Hakikat, (neşr.ismet Miroğlu), ìstanbul 1983.

Mc Carty, Justin, Ölüm ve Sürgün, (çev. Bilge Umar), İstanbul 1998.

Muahedât Mecmuası, C. IV/2., İstanbul 1298.

Özbay, Özdemir, Dünden Bugüne Kuzey Kafkasya, Ankara 1995.

Papşu, Murat "Bir Adlandırma Sorunu, Abhaz mı Abaza mı?" Nart iki Ayıı Düşün ve Kültür Dergisi , S. 51, Eylül-Ekim 2006.

Shaw, Stanford J. - Ezel Kural Shaw, Osmanlı Imparatorluğu ve Modern Türkiye, İstanbul 2000, C.2, s.60.

Sımsım, Selçuk, 19. ve 20. Yüzyıl Abazaların Politik Tarihi (1770-1993), istanbul 2016.

Sürmeli, Serpil, Türk-Gürcü Ilişskileri (1918-1921), Ankara 2001.

Şahin, Enis, Diplomasi ve Sınır, Gümrü Görüşmeleri ve Protokolleri, 1918, İstanbul 2005.

Türk istiklal Harbi, Mondros Mütarekesi ve Tatbikatı, C. I, Ankara 1962.

Zatulin, Konstantin - Yuri Ançabadze, Gürcistan-Abhazya Anlaşmazlığı Dünü, Bugünü, Çözüm Perspektifleri, 1998. 